\title{
Poemas
}

\author{
Pedro Serrano
}

\section{Plan de Tlalcapatla}

Un jacal en que entráramos, techado de niños, carbón al viento y basurillas en los pajares del maizal.

Por ahí las vacas, a la partida de los peones, sin hibernación ni guarida.

Olisqueando huellas humanas, ruido entre nos.

En los escombros, rizos y un camioncito, mechas de palma entre las ruedas, un bule roto y tres piedras tiznadas en señal de hogar.

Sobras de trashumancia luego de la siembra, al cabo de la pizca.

El plan ahora un mar dorado en que nos calentamos como mazorcas al sol en cuaresmal espera.

\section{DE INMOVILIDAD Y ESTAMPIDA}

Pasa el ferrocarril, mis hijos duermen en su playa que es el verano, un paréntesis de quietud $y$ un hueco en el que encaja por un rato la horqueta de un tronco detrás de la maleza, sorprendido. 